\title{
Occurrence of antibodies anti-Toxoplasma gondii among sheltered and free-roaming cats within a university campus
}

\section{Ocorrência de anticorpos anti-Toxoplasma gondii entre gatos de abrigo e de vida livre dentro de um campus universitário}

\author{
Louise Bach Kmetiuk'; Maysa Pellizzaro2; Ana Carolina Yamakawa ${ }^{3}$; Juliana Cristina \\ Rebonato Mendes ${ }^{4}$; Camila Marinelli Martins ${ }^{5}$; Aurea Maria Oliveira Canavessi6; \\ Helio Langoni ${ }^{7}$; Andrea Pires dos Santos ${ }^{8}$; Alexander Welker Biondo ${ }^{9 *}$
}

\section{Highlights}

First report of anti-T. gondii antibodies in free-roaming cats in university campus;

Free-roaming and older cats may be more susceptible to T. gondii infection;

Risk of seropositive T. gondii free-roaming cats overlapping human/livestock areas.

\begin{abstract}
The present study aimed to assess anti-T. gondii antibodies in sheltered and free-roaming cats within a university campus that has an overlapping population of humans and livestock. A total of 51 cats were tested for anti-T. gondii antibodies using the indirect immunofluorescent antibody test. Overall, 8/51 cats $(15.7 \%)$ were seropositive. Cats were more likely to be seropositive when free-roaming $(p=0.008)$ and with

1 Postdoc Scholar, Graduate College of Parasitology, Federal University of Minas Gerais, UFMG, MG, BH, Brazil. E-mail: louisebachk@gmail.com

2 PhD Student, Graduate College of Public Heath, Federal University of Bahia, UFBA, Salvador, BA, Brazil. E-mail: maysa. pellizzaro@gmail.com

3 Master Degree Student, Graduate College of Veterinary Medicine, São Paulo State University, UNESP, Botucatu, SP, Brazil. E-mail: anayamakawa1994@gmail.com

4 Master Degree Student, Graduate College of Molecular Biology, Federal University of Paraná, UFPR, Curitiba, PR, Brazil. E-mail: jcrebonato@hotmail.com

5 Collaborating Profa, Department of Medicine, State University of Ponta Grossa, UEPG, Ponta Grossa, PR, Brazil. E-mail: camimarinelli@gmail.com

6 Faculty Member, University of São Paulo, USP, ESALQ, Piracicaba, SP, Brazil. E-mail: acanavessi@usp.br

7 Full Prof., Department of Veterinary Hygiene and Public Health, São Paulo State University, UNESP, Botucatu, SP, Brazil. E-mail: helio.langoni@unesp.br

8 Assistant Prof., College of Veterinary Medicine, Purdue University, West Lafayette, IN, USA. E-mail: santos1@ purdue.edu

9 Full Prof., Departament of Veterinary Medicine, Federal University of Paraná, UFPR, Curitiba, PR, Brazil. E-mail: abiondo@ ufpr.br

* Author for correspondence
\end{abstract}

Received: July 28, 2020 - Approved: Oct. 08, 2020 
presence of skin lesions $(p=0.042)$, and less likely with $<1$ year of age $(p=0.021)$, probably due to higher environmental exposure and infected prey consumption. The presence of seropositive free-roaming cats whose areas overlapped those occupied by humans and livestock may suggest an increased on-campus chance of T. gondii occurrence.

Key words: Feral cats. Toxoplasmosis. Associated factors.

\section{Resumo}

O presente estudo teve por objetivo acessar anticorpos anti-Toxoplasma gondii em gatos de abrigo e gatos de vida livre dentro de um campus universitário que tem uma população sobreposta de seres humanos e animais de produção. Um total de 51 gatos foram testados para anticorpos anti- $T$. gondii usando o teste de imunofluorescência indireta. No geral, 8/51 (15.7\%) gatos foram soropositivos. Os gatos foram mais propensos a ser soropositivos quando em vida livre $(p=0,008)$ e com lesões de pele $(p=0.042)$, e menos prováveis com menos de 1 ano de idade $(p=0,021)$, provavelmente devido à maior exposição ambiental e consumo de presas infectadas. A presença de gatos errantes soropositivos cujas áreas se sobrepõem àquelas ocupadas por seres humanos e animais pode sugerir um risco aumentado de ocorrência de $T$. gondii no campus.

Palavras-chave: Gatos ferais. Toxoplasmose. Fatores associados.

\section{Introduction}

Toxoplasmosis, caused by the protozoon Toxoplasma gondii, is a widespread zoonotic disease that can infect all warmblooded animals worldwide (Dubey, 2010; Hill \& Dubey, 2016). Felids, including the domestic cat, are the only definitive hosts. They shed millions of oocysts through their feces, following primary infection (Hill \& Dubey, 2016). Intermediate T. gondii hosts, including humans, can be infected through ingestion of environmental oocysts, consumption of undercooked and raw meat containing bradyzoites or transplacental transmission of tachyzoites and by milk (Dubey, 2010; Hill \& Dubey, 2016). The occurrence of anti-T. gondii antibodies in cats has been extensively reported worldwide. In Brazil, seropositivity reported was 4/107 (3.74\%) in feral cats in an environmentally preserved and low demographic density residential area
(Bolais et al., 2017). Another study reported seropositivity among $18 \%(31 / 172)$ stray cats from set of condominiums and $24,5 \%(64 / 261)$ cats from municipal shelter of Rio de Janeiro city, southern Brazil (Pereira et al., 2018). In a previous study, anti- T. gondii antibodies have been detected in 84/237 (35.4\%) of stray cats from 15 counties of São Paulo State, Brazil, southern Brazil (Pena, Soares, Amaku, Dubey, \& Gennari, 2006). As previously shown in a metaanalysis review, seroprevalence of $35.9 \%$ for toxoplasmosis in cats has been observed in Brazil, and higher in north-northeast-central region $(50.5 \%)$ when compared to southsoutheast region (29.9\%) (Lugoch, Noro, \& Andrade, 2019). In addition, pet and feral cats from a touristic oceanic island have shown $71.26 \%(248 / 348)$ seropositivity of T. gondii (Magalhães et al., 2017).

A previous study suggested that unowned cats on the University of São Paulo campus could be environmental sentinels 
for human exposure to Rickettsia spp., the causative agent of Brazilian spotted fever (BSF) (Mendes et al., 2019). Despite the urban location of this University of São Paulo campus, it is composed of extensive green areas and hosts experimental farms on which projects involving all the major animal species of Brazilian economic interest, such as dairy and beef cattle, pigs, sheep, goats, horses and poultry, are conducted (Escola Superior de Agricultura "Luiz de Queiroz" [ESALQ], 2019). The campus is also occupied by around 250 free-roaming cats (Mendes et al., 2019).

Given that human and livestock populations that live together with high populations of cats are likely to be more chance to $T$. gondii infection (Stelzer et al., 2019), a serosurvey was conducted to evaluate the characteristics of Toxoplasma gondii exposure among free-roaming and sheltered on-campus cats.

\section{Materials and Methods}

The study was conducted at the "Luiz de Queiroz" School of Agriculture of the University of São Paulo (Esalq USP), in the municipality of Piracicaba, state of São Paulo, from July to October 2017. The on-campus human population at the time of survey was around 4,500 people including faculties, students, infrastructure and maintenance personal. The animal population within campus at the time was estimated in 250 freeroaming cats overlapping all livestock areas which housed around 750 cattle, 300 sheep, 150 swine, 200 chicken, and 500 fish for experimental purposes. These cats survived by hunting birds and rodents, and were also offered cat food, according to the campus administration. Free-roaming cats and feral cats have a similar habit, regarding the lack of socialization in early stages showing an evasive behavior (Bradshaw, Horsfield, Allen \& Robinson, 1999). In addition, cats living in a temporary on-campus animal shelter were sampled.

To obtain samples from the freeroaming population, traps were distributed in several on-campus locations during a fourmonth trapping period. After trapping and/or physical restraint, blood samples from 35/51 shelter cats $(68.6 \%)$ and $16 / 250$ free-roaming cats (6.4\%) were successfully collected by means of jugular puncture, as previously described (Mendes et al., 2019).

The serum samples were tested for anti-T. gondii antibodies using the indirect immunofluorescent antibody test (IFAT), using titer 16 as a cutoff (Costa et al., 2012; Dabritz et al., 2007) and con-sidering the reaction to be positive if $\geq 50 \%$ fluorescent tachyzoites with conjugate anti-feline an-tibodies were observed (Camargo, 1974). The present study was approved by the Ethics Committee for Animal Use of the Agricultural Sciences Sector of the Federal University of Paraná (Protocol \# 103/2017)

The identification sheet for each animal included sex, age (grouped in up to one year and two or more), fleas presence, ticks presence, lesions presence, clinical signs presence and location (shelter or freeroaming).

Bivariate analysis on location, age, sex, presence of fleas and ticks, skin lesions and clinical signs of $T$. gondii was performed using prevalence ratios, 95\% confidence intervals and chi-square tests. Although this 
is not a study of prevalence, this association measure was used to describe the association level between factors and occurrence of antibodies anti-Toxoplasma gondii. A multiple logistic regression model was performed with significant variables and interactions between them were tested. Descriptive statistics were provided through frequencies and 95\% confidence intervals for seropositivity of $T$. gondii. All tests were considered significant when $p<0.05$. The analyses were done using the SPSS 21.0 software.

\section{Results and Discussion}

Overall, a total of 51 cats were sampled. This sample corresponds to around 20.4\% $(51 / 250)$ of population estimated. A total of $8 / 51$ sampled cats (15.7\%; 7.8-26.7\%) were seropositive for $T$. gondii, including 6/16 freeroaming cats $(37.5 \%)$ and $2 / 35$ sheltered cats (5.7\%).
Seropositivity for $T$. gondii was statistically higher among the free-roaming cats $(6 / 16 ; 37.5 \%)$ than among the shelter cats (2/35; $5.7 \%)$ ( $p=0.008$ ); higher among adults, i.e. two years of age or over $(6 / 21 ; 28.6 \%)$ than among kittens $(1 / 27 ; 3.7 \%)(p=0.021)$; and higher among cats with skin lesions (3/6; $50.0 \%)$ than among cats without skin lesions $(5 / 45 ; 11.1 \%)(p=0.042)$. The other potential associated factors for T. gondii in cats were not statistically significant: $\operatorname{sex}(p=0.626)$, presence of fleas ( $p=0.234)$, presence of ticks ( $p=0.407$ ) or unhealthy clinical signs ( $p=0.367$ ) (Table 1). Interactions between age and local was evaluated and between free-roaming, $25.0 \%(4 / 16)$ are young, $65.7 \%$ $(23 / 35)$ are young between sheltered $(p=0.03)$. The significant variables (local, age and lesions) were evaluated in a multiple logistic model and no significant multiple associations were verified. 
Table 1

Associated factors for T. gondii and prevalence ratios (PR) among free-roaming and sheltered cats within university campus

\begin{tabular}{|c|c|c|c|c|c|}
\hline \multicolumn{2}{|c|}{ T. gondii } & $\begin{array}{c}\text { Total } \\
\text { Yes/Total (\%) }\end{array}$ & $\begin{array}{c}\text { Positive } \\
\text { Yes/Total (\%) }\end{array}$ & PR $(95 \% \mathrm{Cl})$ & p-value ${ }^{*}$ \\
\hline \multicolumn{6}{|c|}{ Bivariated analysis } \\
\hline \multirow{2}{*}{ Cat group } & Shelter & $35 / 51(68.6)$ & $2 / 35(5.7)$ & (ref.) & \\
\hline & Free-roaming & 16/51 (31.4) & $6 / 16(37.5)$ & $6.65(1.48-29.03)$ & 0.008 \\
\hline \multirow{2}{*}{ Age } & Two or more years & $21 / 51(41.2)$ & $6 / 21(28.6)$ & (ref.) & \\
\hline & Up to one year & 27/51 (52.9) & $1 / 27(3.7)$ & $0.13(0.02-0.99)$ & 0.021 \\
\hline \multirow{2}{*}{ Sex } & Male & $25 / 51(49.0)$ & $4 / 25$ (16.0) & (ref.) & \\
\hline & Female & $26 / 51(51.0)$ & $4 / 26(15.4)$ & $0.96(0.21-4.32)$ & 0.626 \\
\hline \multirow{2}{*}{ Fleas } & No & 45/51 (88.2) & $6 / 45$ (13.3) & (ref.) & \\
\hline & Yes & 6/51 (11.8) & 2/6 (33.3) & $2.50(0.64-9.69)$ & 0.234 \\
\hline \multirow{2}{*}{ Ticks } & No & $48 / 51(94.2)$ & $7 / 48(14.6)$ & (ref.) & \\
\hline & Yes & $3 / 51(5.8)$ & 1/3 (33.3) & $2.28(0.40-13.03)$ & 0.407 \\
\hline \multirow{2}{*}{ Lesions } & No & 45/51 (88.2) & $5 / 45(11.1)$ & (ref.) & \\
\hline & Yes & 6/51 (11.8) & $3 / 6(50.0)$ & $4.50(1.42-14.22)$ & 0.042 \\
\hline \multirow{2}{*}{$\begin{array}{l}\text { Clinical } \\
\text { signs }\end{array}$} & No & $43 / 51(84.3)$ & $6 / 43(14.0)$ & (ref.) & \\
\hline & Yes & $8 / 51(15.7)$ & $2 / 8(25.0)$ & $1.79(0.44-7.35)$ & 0.367 \\
\hline \multicolumn{2}{|c|}{ Multiple analysis } & Adjusted PR & Cl $95 \%$ & $\mathrm{p}$-value & \\
\hline \multicolumn{2}{|c|}{ Cat group free-roaming } & 6.87 & $0.66-69.78$ & 0.106 & \\
\hline \multicolumn{2}{|c|}{ Age up to one year } & 1.02 & $0.08-13.34$ & 0.989 & \\
\hline \multicolumn{2}{|c|}{ With Lesions } & 0.15 & $0.01-1.77$ & 0.132 & \\
\hline
\end{tabular}

To the authors' knowledge, the present study is the first report of $T$. gondii occurrence in a high-density population of free-roaming and sheltered cats on-campus, which overlaps with humans and livestock. The occurrence of T. gondii antibodies among the free-roaming cats of the present study $(6 / 16 ; 37.5 \%)$ was higher than what was found among feral cats in southeastern Brazil (4/107; 3.74\%) (Bolais et al., 2017), but was lower than among semidomiciliated and feral cats on an oceanic island in northeastern Brazil (71.26\%; 248/348) (Magalhães et al., 2017). The occurrence of
T. gondii antibodies among the sheltered cats of the present study $(2 / 35 ; 5.7 \%)$ was lower than what was found among captive cats in a municipal shelter in southeastern Brazil (64/261; 24.5\%) (Pereira et al., 2018), but was higher than among sheltered cats in urban areas of Tokyo, Japan (3/119; 2.5\%) (Oi, Yoshikawa, Maruyama, \& Nogami, 2015).

The lower frequency observed in the group of sheltered cats than among the freeroaming cats in the present study $(p=0.008)$ may have occurred due to the limited exposure 
of the sheltered cats to infected food sources. Although the high concentration of sheltered cats may favor contact between potentially contaminated feces and soil (Albuquerque et al., 2011), free-roaming cats' habits of hunting and consumption of infected birds and rodents may result in increased exposure to environmental infection (Magalhães et al., 2017). Moreover, higher prevalence of oocyst shedding has been reported in free-roaming cats when compared to household pets (VanWormer, Fritz, Shapiro, Mazet, \& Conrad, 2013). Also, previous study has shown that unburied feces habit in free-roaming cat colonies, that may favor widespread T. gondii oocyst through-out the environment (Ruiz \& Frenkel, 1980).

In addition, free-roaming cats that present with skin lesions were more likely to be seropositive than were those without skin lesions ( $p=0.042)$. Occurrence of skin lesions has previously been correlated with roaming and fighting habits, thereby increasing the chance of contact and/or spread of $T$. gondii oocysts (Hughes \& Slater, 2002).

The combination of hunting and ingestion of contaminated prey by the freeroaming on-campus cats, combined with highly contaminated soil and an isolated area may perpetuate the protozoan cycle and, thus, increase the chance of $T$. gondii transmission to humans and livestock. This combination was previously observed as an "island effect" among feral cats living at a well-known Brazilian touristic destination, the island Fernando de Noronha (Magalhães et al., 2017). As expected, cats older than one year of age in the present study were more likely to be seropositive for T. gondii than were younger cats, considering that it has previously been reported that older cats showed higher chances of exposure due to longer exposure (Must, Hytönen, Orro, Lohi, \& Jokelainen, 2017). In addition, oocyst shedding has been reported in adult cats under natural infection, with significant role of T. gondii transmission cycles (Berger-Schoch et al., 2011).

Given that the present study showed relatively high seropositivity among freeroaming cats $(37.5 \%)$, the on-campus populations of both humans and livestock may be more chance to T. gondii infection and should be further investigated. Although not estimated in the present study, it had previously been shown that the average home range among free-roaming cats is $1.2 \mathrm{~km}$, between successive home ranges (Edwards, De Preu, Shakeshaft, Crealy, Paltridge, 2001). This may have an impact on human toxoplasmosis outbreaks, given that T. gondii oocysts shed by cats are present in the soil in these farm areas (Coutinho, Lobo, \& Dutra, 1982; Shenep, Barenkamp, Brammeier, \& Gardner, 1984).

Livestock animals may be more chance to toxoplasmosis outbreaks, since presence of cats has been correlated with $\mathrm{T}$. gondii infection on livestock farms. There is a high chance that these cats will shed T. gondii oocysts and contaminate farmland, water and livestock food (Stelzer et al., 2019). Moreover, the chance of $T$. gondii infection in cattle may also increase twofold in the presence of more than three cats $(p=0.0138$ ) living on the farm (Albuquerque et al., 2011). Thus, in the present study, the on-campus presence of T. gondii-seropositive free-roaming cats in areas overlapping with those of humans and livestock animals may have significantly favored T. gondii occurrences in all these populations. 
A limitation of this study is the lack of representative sampling due to free-roaming cats. Despite all cats captured during the available time were included in the study, mostly cats were afraid of human contact and trapping yield was unpredictable. As previous studies have shown sample sizes ranging from $2 \%$ to $80 \%$ of sampled cats, the study herein should be around 27 to 124 cats (simple random sampling with $95 \%$ of confidence and $5 \%$ of precision). Thus, results may be used as a first and initial evaluation of anti-T. gondii antibody occurrence, and further studies may be required to be fully establish the overall prevalence in such cat population.

\section{Conclusions}

In conclusion, the present study provides the first report on anti-T. gondii antibodies occurrence among free-roaming and sheltered cats whose area overlapped with areas occupied by populations of humans and livestock on a university campus. Free-roaming cats, cats with presence of skin lesions and cats older than one year of age may be more susceptible to $T$. gondii infections, probably due to higher chances of environmental exposure, particularly associated with consumption of infected prey. Lastly, the presence of seropositive free-roaming cats whose areas overlapped those occupied by humans and livestock may suggest that there was an increased oncampus chance of T. gondii occurrence.

\section{Conflict of interest}

The authors declare that they did not have any competing interests.

\section{References}

Albuquerque, G. R., Munhoz, A. D., Teixeira, M., Flausino, W., Medeiros, S. M., \& Lopes, C. W. G. (2011). Risk factors associated with Toxoplasma gondii infection in dairy cattle, state of Rio de Janeiro. Pesquisa Veterinária Brasileira, 31(4), 287-290. doi: 10.1590/S0100-736X2011000400003

Berger-Schoch, A. E., Herrmann, D. C., Schares, G., Müller, N., Bernet, D., Gottstein, B., \& Frey, C. F. (2011). Prevalence and genotypes of Toxoplasma gondii in feline faeces (oocysts) and meat from sheep, cattle and pigs in Switzerland. Veterinary Parasitology, 177(3-4), 290-297. doi: 10. 1016/j.vetpar.2010.11.046

Bolais, P. F., Vignoles, P., Pereira, P. F., Keim, R., Aroussi, A., Ismail, K.,... Mercier, A. (2017). Toxoplasma gondii survey in cats from two environments of the city of Rio de Janeiro, Brazil by modified agglutination test on sera and filter-paper. Parasites \& Vectors, 10(1),88. doi: 10.1186/s13071-017-2017-8.

Bradshaw, J. W., Horsfield, G., Allen, J., \& Robinson, I. (1999). Feral cats: their role in the population dynamics of Felis catus. Applied Animal Behaviour Science, 65(3), 273-283. doi: 10.1016/s0168-1591(99) 00086-6

Camargo, M. E. (1974). Introdução às técnicas de imunofluorescência. Revista Brasileira Patologia Clínica, 10(3), 87-107.

Costa, D. G. C., Marvulo, M. F. V., Silva, J. S. A., Santana, S. C., Magalhães, F. J. R., Lima, C.D. F., Fo ,.... Silva, J. C. R. (2012). Seroprevalence of Toxoplasma gondii in domestic and wild animals from the Fernando de Noronha, Brazil. Journal of Parasitology, 98(3), 679680. doi: 10.1645/GE-2910.1 
Coutinho, S. G., Lobo, R., \& Dutra, G. (1982). Isolation of Toxoplasma from the soil during an outbreak of toxoplasmosis in a rural area in Brazil. The Journal of Parasitology, 68(5), 866-868. doi: 10.2307/3280995

Dabritz, H. A., Gardner, I. A., Miller, M. A., Lappin, M. R., Atwill, E. R., Packham, A. E.,... Conrad, P. A. (2007) Evaluation of two Toxoplasma gondii serologic tests used in a serosurvey of domestic cats in California. Journal of Parasitology, 93(4), 806-816. doi: 10.1645/ GE-996R.1

Dubey, J. P. (2010). Toxoplasmosis of animals and humans (2nd ed.). Florida: CRC Press.

Edwards, G. P., De Preu, N., Shakeshaft, B. J., Crealy, I. V., \& Paltridge, R. M. (2001). Home range and movements of male feral cats (Felis catus) in a semiarid woodland environment in central Australia. Austral Ecology, 26(1), 93-101. doi: 10.1111/j.14 42-9993.2001.01091.pp.x

Escola Superior de Agricultura "Luiz de Queiroz" (2019). Universidade de São Paulo - USP. ESALQ em números. Piracicaba: USP. Recuperado de https://www.esalq.usp.br/ institucional/esalq-em-numeros

Hill, D. E., \& Dubey, J. P. (2016). Toxoplasma gondii as a parasite in food: analysis and control. Microbiology Spectrum, 4(4), 227. doi: 10.1128/microbiolspec.PFS-0011-2015

Hughes, K. L., \& Slater, M. R. (2002). Implementation of a feral cat management program on a University Campus. Journal of Applied Animal Welfare Science, 5(1), 1528. doi: 10.1207/s15327604jaws0501_2

Lugoch, G., Noro, M., \& Andrade, J. (2019). Meta-analysis of the prevalence of toxoplasmosis in cats and sheep in Brazil.
Revista de Ciência Veterinária e Saúde Pública, 6(1), 41-70. doi: 10.4025/revcivet. v6 i1.41361

Magalhães, F. J. R., Ribeiro-Andrade, M., Souza, F. M., Lima, C. D. F., Fo., Biondo, A. W., Vidotto, O.,... Mota, A. M. (2017). Seroprevalence and spatial distribution of Toxoplasma gondii infection in cats, dogs, pigs and equines of the Fernando de Noronha Island, Brazil. Parasitol International, 66(2), 43-46. doi: 10.1016/j.parint.2016.11.014

Mendes, J. C. R., Kmetiuk, L. B., Martins, C. M., Canavessi, A. M. O., Jimenez, T., Pellizzaro, M.,... Biondo, A. W. (2019). Serosurvey of Rickettsia spp. in cats from a Brazilian spotted fever-endemic area. Revista Brasileira de Parasitologia Veterinária, 28(4), 713-721. doi: 110.1590/S1984-29 612019092

Must, K., Hytönen, M. K., Orro, T., Lohi, H., \& Jokelainen, P. (2017). Toxoplasma gondii seroprevalence varies by cat breed. PLOS One, 12(9), e0184659. doi: 10.1371/ journal.pone.0184659

Oi, M., Yoshikawa, S., Maruyama, S., \& Nogami, S. (2015). Comparison of Toxoplasma gondii seroprevalence in shelter cats and dogs during 1999-2001 and 2009-2011 in Tokyo, Japan. PLOS One, 10(8), e0135956. doi: 10.1371/journal.pone.0135956

Pena, H. F. J., Soares, R. M., Amaku, M., Dubey, J. P., \& Gennari, S. M. (2006). Toxoplasma gondii infection in cats from São Paulo state, Brazil: Seroprevalence, oocyst shedding, isolation in mice, and biologic and molecular characterization. Research in Veterinary Science, 81(1), 58-67. doi: 10. 1016/j.rvsc.2005.09.007 
Pereira, P. F., Barbosa, A. S., Santos, A. L. C., Bolais, P. F., Dardé, M. L., \& Amendoeira, M. R. R. (2018). Toxoplasma gondii: infection among shelter and stray cats in Rio de Janeiro, Brazil. Revista Brasileira de Parasitologia Veterinária, 27(3), 401-408. doi: 10.1590/s1984-296120180061

Ruiz, A., \& Frenkel, J. (1980). Toxoplasma gondii in Costa Rican cats. American Journal of Tropical Medicine and Hygiene, 29(6), 1150-1160. doi: 10.4269/ ajtmh.1980.29.1150

Shenep, J. L., Barenkamp, S. J., Brammeier, S. A., \& Gardner, T. D. (1984) An outbreak of toxoplasmosis on an Illinois farm. Pediatric Infectious Disease, 3(6), 518-522. doi: 10.1097/00006454-198411000-00007
Stelzer, S., Basso, W., Silván, J. B., Ortega-Mora, L. M., Maksimov,P., Gethmann, J.,... Schares G. (2019). Toxoplasma gondii infection and toxoplasmosis in farm animals: Risk factors and economic impact. Food and Waterborne Parasitology, (15), e00037. doi: 10.1016/j.fawpar.2019.e00037

VanWormer, E., Fritz, H., Shapiro, K., Mazet. J. A. K., \& Conrad, P. (2013). Molecules to modeling: Toxoplasma gondii oocysts at the human-animal-environment interface. Comp Immunol Microbiol Infect Dis, 36(3), 217-231. doi: 10.1016/j. cimid.2012.10.006 
